\title{
FOOD CONSUMPTION PATTERN OF TRIBAL FAMILIES IN NALGONDA DISTRICT, ANDHRAPRADESH
}

\author{
RAJESWARI K ${ }^{1} \&$ PRASHANTHI MEDA ${ }^{2}$ \\ ${ }^{I}$ Teaching Associate, Pg\&RC, Professor Jayashankar Telanagana State Agricultural University Rajendranagar,
} Hyderabad,Telanagana State, India

${ }^{2}$ Research Associate, All India Coordinated Research Project on Home Science, Professor Jayashankar Telanagana State Agricultural University Rajendranagar, Hyderabad, Telanagana State, India

\begin{abstract}
A study was conducted to assess the food consumption pattern of tribal households in the rural areas of Nalgonda district, Andhra Pradesh (A. P.). Data pertaining to the consumption pattern of different foods was collected with the help of a structured questionnaire. Food and nutrient intake of the family members was assessed using 24-hour recall method. Consumption units were taken into consideration while calculating the individual food and nutrient intake. A total of 11,537 tribal households from rural areas of Nalgonda district were included in this study. The results of the study showed that rice was the staple food consumed by the population. Consumption of fats \& oils, sugar \& jaggery and roots \& tubers was below recommended daily intake (RDI). Similarly, the diets of the households were also grossly deficient in micronutrients, especially iron, vitamin $C$ and not meeting the Recommended Daily Allowances. This could be due to the poor intake of green leafy vegetables and fruits. Based on the results, it is felt that through health and nutrition education, we can bring change in the food consumption pattern. Promoting kitchen gardens in the villages also plays an important role in improving the in take of iron and vitamin $C$ by increasing access and availability of green leafy vegetables.

KEYWORDS: Frequency of Consumption of Foods, Food Intake, Nutrient Intake, Consumption Units, Tribal Families, Recommended Dietary Allowances \& Percent Adequacy of Nutrients
\end{abstract}

Received: Sep 30, 2017; Accepted: Oct 21, 2017; Published: Nov 11, 2017; Paper Id.: IJASRDEC201727

\section{INTRODUCTION}

Rural communities subsisting on inadequate diets, both in terms of quality and quantity, leading to protein, energy and micronutrient malnutrition. The diet and nutrition surveys carried out by the National Nutrition Monitoring Bureau (NNMB) and the National Institute of Nutrition (NIN) in 12 states of country revealed that the diets of the rural population are inadequate and deficient in most of the nutrients. There is widespread energy deficiency in the rural households.

The time trends (NNMB, 1999) also showed that the mean intake of protective foods such as pulses and legumes and non-leafy vegetables continues to be low and was below the recommended dietary intakes (RDI) for Indians (ICMR, 1981), while the consumption of green leafy vegetables (GLV), a rich source of vitamins and minerals, was grossly deficient during the three points of time, that is 1975-1979, 1988-1990 and 1996-1997. This reflected the median intakes of micronutrients like iron, vitamin A and folic acid, which were grossly deficient in the diet of the rural community. This also reflected on the nutritional status of the rural community as per NCHS standards (Hamill et al. 1979). Plant Food such as cereals, pulses and legumes, green leafy and non leafy vegetables 
and roots and tubers form bulk of the Indian diets (Saxena et al., 2007). These food are important part of the diet in the rural areas as they play a very significant role in food security. However, published data on the consumption pattern of foods at district is level are not readily available. The purpose of this communication was to assess consumption pattern of different food groups among rural families of Nalgonda district, Andhra Pradesh.

\section{MATERIALS AND METHODS}

The study was conducted in Nalgonda district of Andhra Pradesh. A total 11537 tribal families from 53 villages were surveyed from the Nalgonda district of Andhra Pradesh. Using a structured questionnaire, information on family size, literacy status, occupation of the heady of the family, and income of the families was collected.

Data pertaining to frequency of food consumption was collected with the help of questionnaires and structured interviews by a trained field assistant in the study villages. The standard diet survey equipment including containers of six consecutive sizes, spoons, and glasses and serving bowls were shown to the person(s) who take care of the cooking part of the household (wife or daughter or daughter in laws or others included). This facilitated the respondents to indicate the exact amount of foods consumed by each family member of the household.

The average daily consumption of various foods and nutrients were computed per consumption unit at the household level using food composition tables (Gopalan 1996). The average daily intake of foods was compared with the Recommended Dietary Intakes for Indians (ICMR, 1981), while that of nutrients was compared with the Recommended Dietary Allowances (ICMR, 1988) in terms of percent adequacy.

\section{RESULTS AND DISCUSSIONS}

\section{General Information}

Table 1: Distribution of Families ( $\mathrm{N}=11537)$

\begin{tabular}{|c|c|}
\hline Particulars & No. $(\%)$ \\
\hline \multicolumn{2}{|c|}{ Gender } \\
\hline Female & $1608(14.0)$ \\
\hline Male & $9929(86.0)$ \\
\hline \multicolumn{2}{|c|}{ Family Size } \\
\hline 1 to 4 members & $6345(55)$ \\
\hline 5 to 7 members & 4961(43) \\
\hline$>=8$ members & $231(2)$ \\
\hline Average family size & $3.9(100)$ \\
\hline \multicolumn{2}{|c|}{ Literacy status } \\
\hline Illiterates & $7111(61.6)$ \\
\hline Literates & $4426(38.4)$ \\
\hline \multicolumn{2}{|c|}{ Occupation } \\
\hline Agriculture & $6017(52)$ \\
\hline Agricultural labor & $3876(34)$ \\
\hline Other labor & $857(8)$ \\
\hline Business & $285(2)$ \\
\hline Government employee & $310(3)$ \\
\hline Private Employee & 192(2) \\
\hline \multicolumn{2}{|c|}{ Income } \\
\hline$<5000 /-$ & $6059(52.5)$ \\
\hline $5000-10000 /-$ & $3983(34.5)$ \\
\hline$>10000 /-$ & $1495(13.0)$ \\
\hline
\end{tabular}


In majority of the families, males (86\%) were found to be the head of the family and only in $14 \%$ families, head of the family were females.

The family size was 1-4 members in 55\% of the families followed by 5-7 members in $43 \%$ of families and greater than 8 members in $2 \%$ of the families. The average size of the family was 3.9. With regard to the literacy status of the head of the family, $61.6 \%$ were illiterates and the rest were literates.

Agriculture is the main livelihood in majority of families (50\%) followed by agricultural labor (34\%), other labor activities (8\%), then business (3\%) followed by employment in private sector (2\%). The annual income of the family was found to be less than Rs. 5000/- in 52.5\% of the families followed by Rs.5000 to 10000 in $34.5 \%$ families and more than Rs. 10,000 in $13 \%$ families.

Table 2: Distribution of Households by Type of Food Habits

\begin{tabular}{|l|l|}
\hline Type of Food Habit & Number (\%) \\
\hline Vegetarians & $174(01.50)$ \\
\hline Non-vegetarians & $11363(98.5)$ \\
\hline Total & $11537(100.0)$ \\
\hline
\end{tabular}

Majority of the families were non-vegetarians (98.5\%).

\section{FOOD CONSUMPTION PATTERN}

Table 3: Frequency of Food Consumption by the Families $(\mathrm{N}=11537)$

\begin{tabular}{|c|c|c|c|c|c|c|c|c|}
\hline \multirow[b]{2}{*}{ Food Groups } & \multicolumn{8}{|c|}{ Percentage of Households Consuming } \\
\hline & Daily & $\begin{array}{l}\text { 5-6 Times } \\
\text { Weekly }\end{array}$ & $\begin{array}{l}\text { 3-4 Times } \\
\text { Weekly }\end{array}$ & $\begin{array}{c}\text { 1-2 } \\
\text { Times } \\
\text { Weekly }\end{array}$ & $\begin{array}{l}\text { 2-3 Times } \\
\text { Monthly }\end{array}$ & $\begin{array}{l}\text { Once In } \\
\text { A Month }\end{array}$ & Rarely & $\begin{array}{l}\text { Not at } \\
\text { all used }\end{array}$ \\
\hline \multicolumn{9}{|c|}{ Cereals } \\
\hline Rice & 100.0 & 0.0 & 0.0 & 0.0 & 0.0 & 0.0 & 0.0 & 0.0 \\
\hline Wheat & 4.5 & 2.6 & 13.1 & 26.3 & 17.0 & 14.2 & 13.7 & 8.5 \\
\hline Jowar & 19.4 & 2.2 & 6.0 & 15.4 & 11.4 & 8.9 & 13.8 & 22.9 \\
\hline Maize & 0.5 & 0.5 & 2.8 & 4.0 & 9.3 & 12.2 & 16.9 & 53.8 \\
\hline Pearl millet & 1.3 & 0.3 & 2.3 & 8.6 & 6.5 & 8.3 & 10.0 & 62.7 \\
\hline \multicolumn{9}{|c|}{ Pulses } \\
\hline Red gram dhal & 0.3 & 3.1 & 22.9 & 56.5 & 8.6 & 2.3 & 1.5 & 4.8 \\
\hline Bengalgram dhal & 0.5 & 1.5 & 5.9 & 20.7 & 26.6 & 24.3 & 11.1 & 9.4 \\
\hline Black gram dhal & 0.6 & 1.2 & 5.4 & 12.3 & 23.3 & 18.6 & 20.8 & 17.8 \\
\hline Green gram dhal & 0.1 & 0.8 & 6.5 & 24.3 & 37.2 & 8.1 & 6.9 & 16.1 \\
\hline Soya bean & 0.1 & 0.6 & 2.8 & 4.5 & 5.6 & 11.1 & 18.4 & 56.9 \\
\hline Peas & 0.1 & 0.4 & 1.8 & 4.7 & 9.4 & 16.0 & 26.0 & 41.6 \\
\hline Horse gram & 0.5 & 0.4 & 2.5 & 8.8 & 6.4 & 8.1 & 12.2 & 61.1 \\
\hline $\begin{array}{l}\text { Green Leafy } \\
\text { Vegetables }\end{array}$ & 2.3 & 7.5 & 19.6 & 34.1 & 26.8 & 4.9 & 1.1 & 3.7 \\
\hline Other vegetables & 44.3 & 3.3 & 7.5 & 19.0 & 10.4 & 4.7 & 1.1 & 9.7 \\
\hline Roots \& Tubers & 0.4 & 3.1 & 19.4 & 44.9 & 15.5 & 6.3 & 3.2 & 7.2 \\
\hline Fruits & 9.5 & 4.1 & 17.0 & 33.0 & 19.4 & 6.8 & 3.5 & 6.7 \\
\hline $\begin{array}{l}\text { Milk \& Milk } \\
\text { products }\end{array}$ & 51.5 & 2.3 & 6.2 & 14.4 & 12.4 & 4.2 & 3.8 & 5.2 \\
\hline Chicken & 0.3 & 0.7 & 6.7 & 35.1 & 42.6 & 8.2 & 2.2 & 4.2 \\
\hline Mutton & 0.1 & 0.3 & 3.1 & 26.7 & 30.5 & 26.5 & 4.8 & 8.0 \\
\hline Cow or buffalo & 0.1 & 0.1 & 0.9 & 5.7 & 4.0 & 3.4 & 2.1 & 83.7 \\
\hline Pig & 0.0 & 0.0 & 0.2 & 0.7 & 1.3 & 1.8 & 2.0 & 94.0 \\
\hline Sea foods & 0.6 & 1.1 & 7.0 & 19.6 & 22.4 & 21.2 & 15.1 & 13.0 \\
\hline
\end{tabular}




\begin{tabular}{|l|c|c|c|c|c|c|c|c|}
\hline \multicolumn{9}{|c|}{ Table 3: Contd., } \\
\hline Fats \& Oils & 96.0 & 0.0 & 0.1 & 0.1 & 0.1 & 0.3 & 0.3 & 3.1 \\
\hline Sugar \& Jaggery & 2.7 & 3.4 & 4.7 & 17.5 & 24.9 & 14.7 & 24.6 & 7.5 \\
\hline
\end{tabular}

\section{Cereals \& Millets}

Frequency of food consumption of families is clearly given in table 3. From the table, it is evident that the rice was the most commonly consumed cereal among the households. $100 \%$ of the households reported consuming rice daily. It is more acceptable due to its longer shelf life, easy availability throughout the year and organoleptic acceptability. Jowar is another most commonly used cereal in Nalgonda district. About $19.4 \%$ of households reported consuming jowar daily whereas about $15.4 \%$ and $11.4 \%$ households reported consuming jowar once or twice weekly and two to three times monthly respectively. About $22.9 \%$ of the households reported not consuming the jowar in any form. Few reported consuming rotis of jowar and rice flour mixture.

Very few families reported consuming maize and pearl millet. None of the family consume ragi in these villages. Consumption of wheat was once or twice weekly by $26.3 \%$ of the families, followed by two to three times monthly $17.0 \%$, once in a month by $14.2 \%$ and weekly three to four by $13.1 \%$ of the families. The percentage of families consuming wheat was also quite higher in the study area, which might be due to the supply through the Public Distribution System at lower price.

\section{Pulses}

Only $0.6 \%$ of the families reported consuming pulses daily. Majority of the households reported consuming pulses either once or twice daily or two to three times monthly. Majority of the families reported the consumption of pulses is more during summer season during which time the availability of vegetables is very less in the villages.

Among the pulses, red gram dhal consumption was the most common pulse consumed, and about 56.5\% families reported that they consume two to three times weekly. Other pulses like green gram (37.2\%), bengal gram (26.6\%), black gram $(23.3 \%)$, were also found to be consumed less frequently, about two to three times in a month. None of them reported consuming either soya or peas. About $8.8 \%$ of the families reported consuming horse gram two to three times a week.

\section{Green Leafy Vegetables}

Only $2.3 \%$ of the households reported consuming leafy vegetables daily, whereas the consumption was one to two times a week by $34.1 \%$ of the families, three to four times a week by $26.8 \%$, and $19.6 \%$ reported two to three times monthly respectively. About $3.7 \%$ of families reported not consuming green leafy vegetables. They do not prefer to buy vegetables from the vegetable market, but they consume whatever is available in the village or is grown in their fields during different seasons. The commonly consumed green leafy vegetables include gogu, fenugreek, palak and curry leaves.

\section{Other Vegetables}

Frequency of consumption of other vegetables was daily by $44.3 \%$ of families and $9.7 \%$ of the families reported not consuming other vegetables. The commonly consumed vegetables included tomato, brinjal, ladies finger, bitter gourd, bottle gourd, cluster beans, cucumber, etc, and these are mostly grown in their own fields.

\section{Roots \& Tubers}

About $44.3 \%$ of the households reported consuming roots \& tubers once or twice weekly. The major roots \& 
tubers consumed by the household members included are ginger, garlic, potato and colacasia. The roots \& tubers like carrot, beetroot and radish were found to be consumed very less, which could be due to the high price and unavailability. About $7.1 \%$ of the households reported not consuming the roots and tubers at all. Among all roots and tubers, potato was found to be consumed more due to the plentiful availability throughout the year at low price.

\section{Fruits}

Only $9.5 \%$ of the families were found to be consuming the fruits daily. About $33.0 \%$ of the families found to consume fruits once or twice a week. The fruits consumed by the families were mostly sweet limes, guava, bananas, mangoes and grapes. The consumption was mostly restricted to seasonal availability.

\section{Milk and Milk Products}

Consumption of milk and milk products was daily in $51.5 \%$ of the families whereas $5.1 \%$ of families reported not consuming any milk products. In the survey area, majority of the families have milk animals. Goat and cow milk were found to be consumed by the majority of the families. Butter milk was found as major milk product consumed by the majority of families compared other products.

\section{Fats \& Oils}

Around $96.0 \%$ of the families were using oil daily and only $3.1 \%$ of families mentioned they were not using oil.

\section{Non Vegetarian Foods}

Consumption of non-vegetarian foods was only two to three times monthly in majority of families. Among the non-vegetarian foods, chicken was the most preferred one and consumed by $42.6 \%$ of the families, followed by mutton by $30.5 \%$ families and then fish by $22.4 \%$ of the families. However, in the study area, each family was found to be rearing hens and goats exclusively for consumption purpose. About $4 \%$ of the families reported consuming beef and $1.3 \%$ pork.

\section{Food Intake (G/CU/Day)}

The average consumption levels for various foods ( $\mathrm{g} / \mathrm{CU} / \mathrm{day}$ ) by the households as per cent of RDA is presented in the table 4 . The average intake of all the foods except cereal and millets ( $488 \mathrm{~g})$ was lower than the RDA.

The intake of various foods ( $\mathrm{g} / \mathrm{cu} / \mathrm{day}$ ) by the family members in comparison with the RDA is presented in Figure 1. The extent of deficit was relatively more with respect to protective foods such as fruits, green leafy vegetables, milk and milk products, sweets, and fats and oils.

Table 4: Average Food Intake (G/CU/Day) of the Families (N=11537)

\begin{tabular}{|l|c|c|c|}
\hline \multicolumn{1}{|c|}{ Foods } & RDA & Present Study & Percent Adequacy \\
\hline Cereals \& Millets & 460 & 488 & 106 \\
\hline Pulses & 40 & 20 & 50 \\
\hline Green Leafy Vegetables & 40 & 4 & 10 \\
\hline Other Vegetables & 60 & 72 & 120 \\
\hline Roots \& Tubers & 50 & 9 & 18 \\
\hline Fruits & 40 & 0 & 0 \\
\hline Milk and milk products & 150 & 39 & 26 \\
\hline Sweets & 30 & 0 & 0 \\
\hline Non vegetarian foods & 10 & 7 & 65 \\
\hline \multicolumn{4}{|c|}{ Table 4: Contd., } \\
\hline
\end{tabular}




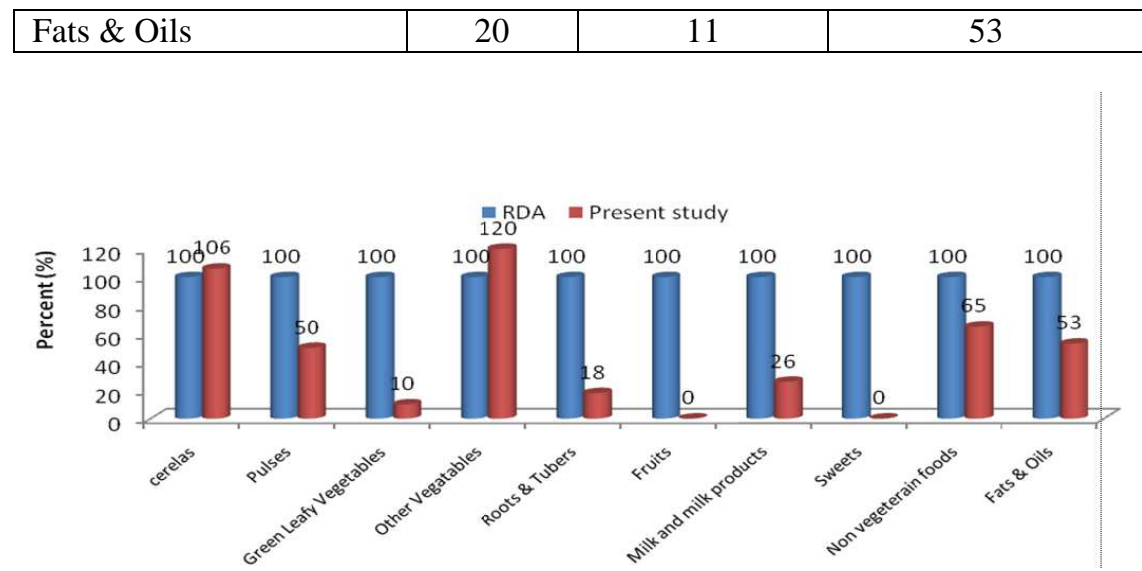

Similar results were also reported earlier by Chaudary (1997) and Vasista (2002). The dietary surveys carried out by NNMB between 1994-1996 also showed that cereals and millets contribute to 60 percent of the total diet and the intake of cereal was about 75 percent of the suggested dietary intake. Agarwal et al., (1999) reported that the diets of rural populations mostly contained cereals and millets and were devoid of green leafy vegetables.

\section{Nutrient Intake (CU/Day)}

Table 5: Average Nutrient Intake (/CU/Day) of the Families ( $N=11537)$

\begin{tabular}{|l|c|c|c|}
\hline Nutrient Intake (CU/Day) & RDA & Present Study & Percent Adequacy \\
\hline Energy (Kcal) & 2425 & 1980 & 82 \\
\hline Protein $(\mathrm{g})$ & 60 & 49 & 82 \\
\hline Fat $(\mathrm{g})$ & 25 & 16.7 & 67 \\
\hline Iron $(\mathrm{mg})$ & 28 & 6 & 21 \\
\hline Calcium $(\mathrm{mg})$ & 400 & 262 & 66 \\
\hline Vitamin C (mg) & 40 & 18 & 45 \\
\hline
\end{tabular}

The average intake of various nutrients (per CU/day) by the households, expressed as percent RDA (percent adequacy), is presented in Table 5. The intake of all nutrients was lower than the RDA.

The extent of deficit was found to be highest with respect to iron (21\%), vitamin C (45\%) fat (67\%), and calcium $(66 \%)$. The proportion of households consuming various nutrient in levels of $<50 \%$ of RDA was highest for iron and vitamin C. This could be due to low consumption of fruits.

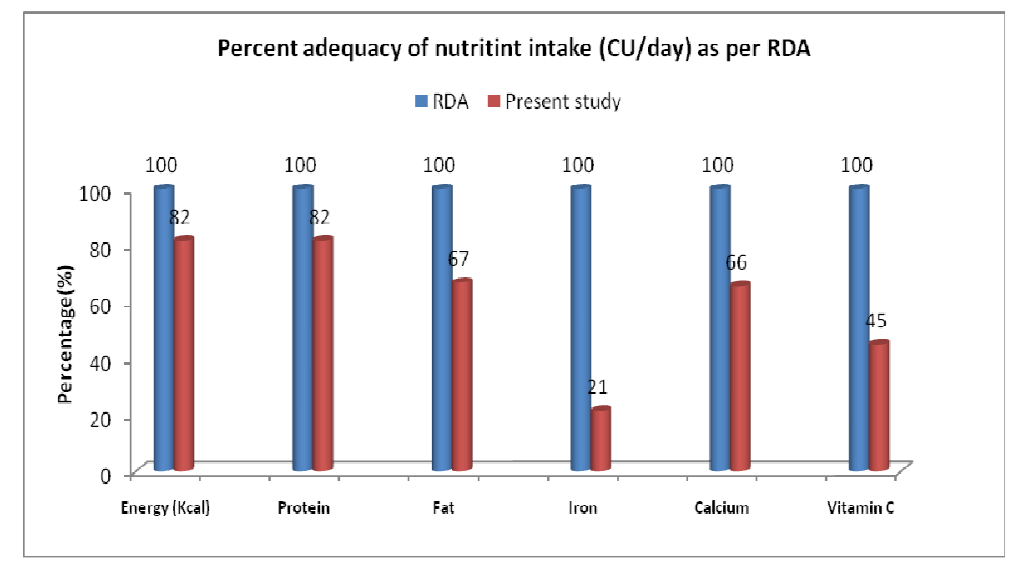

Studies carried out by National Nutrition Monitoring Board (NNMB) in different states revealed that, even though there has been marked decrease in prevalence of overall severe under nutrition over a period of three decades, the 
prevalence of under nutrition continues to be still high. The present study revealed that though the intake of staple foods such as cereals and millets was satisfactory, the protective foods such as green leafy vegetables, fruits, and milk and milk products was significantly low compared to the recommended quantities. This was reflected by the gross inadequacy in the intake of micronutrients like vitamin $\mathrm{A}$, vitamin $\mathrm{C}$, iron, and calcium.

Because of the non availability of some of the foods, poverty, religious factors and ignorance, the daily mean intake of almost all food stuffs, i.e. cereals, pulses, roots and tubers, green leafy vegetables, other vegetables, fruits, fats and oils, milk and milk products and sugar and jaggery was lower than the RDI among the households but comparatively the intake of green leafy vegetables and fruits was lowest. The findings of the present study corroborate with those of Vijaraghavan and Rao (1998) and Nana et al., (2003) who revealed that daily intake of cereals, roots and tubers, green leafy vegetables, fats and oils was lower than the RDI.

\section{CONCLUSIONS}

From the study, It was found that the average intake of all the foods except cereals and vegetables was lower than the RDI among the tribal population of Nalgonda District of Andhra Pradesh. The extent of deficit was relatively more with respect to protective foods such as fruits, green leafy vegetables, milk and milk products. Wide variation in the intake of various foods by the population was due to differences in cropping patterns and economic status of the households.

There is a need to improve the household consumption of protective foods such as green leafy vegetables; fruits etc., through dietary diversification by promoting home gardening. This may improve the consumption of leafy vegetables. Course related to Foods \& Nutrition may be included in the curriculum of children so as to establish sound food habits among them for leading a healthy life.

The community also should be sensitized towards health benefits of consumption of protective foods such as leafy vegetables, fruits, milk \& milk products through health and nutrition education.

\section{REFERENCES}

1. Agarwal, K., Kushwah, A., Kushwah, H.S., Agarwal, R. and Rajput, L.D. 1999. Dietary analysis and Assessment of Nutritional Status of Preschool Children of Urban and Rural Population", Indian Journal of Nutrition and Dietetics. 38: 231-5

2. Chaudhary, P. 1997. Studies on Prevalence and Causes of Iodine Deficiency Disorders in Endemic and Non-Endemic Areas of Haryana. PhD Thesis, CCS, Haryana Agricultural University, Hisar.

3. Gopalan C, Rama Sastri B.V and Balasubrsmanian. 2007. Nutritive value of Indian foods. National Institute of Nutrition (Indian Council of Medical Research), Hyderabad, India.

4. Hamill, P.V.V., Drizd, T.A., Johnson, C.L., Reed, R.B., Roche, A.F and Moore, W.M. 1979. Physical Growth: National Centre for Health and Statistics Percentiles. American Journal of Clinical Nutrition. 32:607-629.

5. Indian Council of Medical Research (ICMR) Expert group. 1981. Recommended Dietary Intakes for Indians. Indian Council of Medical Research, New Delhi.

6. Nana, C.P., Brouwer,I. and Traore, A.S. 2003. Food Consumption of Children 6-36 Months Old in Rural Area in Relation to Micronutrients Rich Foods Availability. Human Nutrition Epidemiology, Available at www.univ.ouaga.Bfffn.zouaga2003 abstract. 
7. National Nutrition Monitoring Bureau (NNMB) (1999). Repeat Surveys Report No.18. National Instistute of Nutrition (Indian council of medical research), Hyderabad, India.

8. Saxena, R. Venkaiah, K, Anitha, P, Venu, L and Raghunath, M. 2007. Antioxidant Activity of Commonly Consumed Plant Foods of India: Contribution of Their Phenolic Content. International Journal of Food Science and Nutrition. 58(4):25-6.

9. Vashista, R. 2002. A Study on Dietary Pattern and Nutritional Status of Pre-Schoolers of Mohindergarh district. MSc. Thesis, CCSHAU, Hisar.

10. Vijayaraghvan, K. and Rao, H.D. 1998. Diet and Nutrition Situations in Rural India. Indian Journal of Medical Research. $108: 243-53$ 